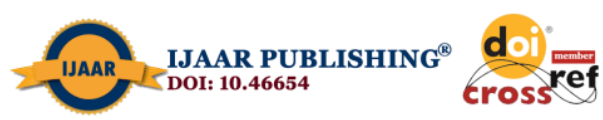

International Journal of Advanced Academic Research (Social and Management Sciences) | ISSN: 2488-9849 Vol. 6, Issue 6 (June, 2020) | www.ijaar.org

Journal DOI: 10.46654/ij.24889849

Article DOI: 10.46654/ij.24889849.s667

\title{
HUMAN RESOURCE TRAINING AND ITS IMPACT ON WORKERS PERFORMANCE OF ISAAC JASPER BORO COLLEGE OF EDUCATION SAGBAMA, BAYELSA STATE, NIGERIA
}

\author{
${ }^{1}$ Ojoh James \\ ${ }^{2}$ Ogbomah, O. Frank \\ ${ }^{1}$ Department of Public Administration, Delta State Polytechnic, Ozoro. \\ ${ }^{2}$ Department of Public Administration, Bayelsa State Polytechnic, Aleibiri.
}

\begin{abstract}
Human resource is the heart of every organization, this is because every other resources such as money, material, machinery all depend on the human resource for effective utilization in order to achieve the goals of the organization. For the human resource to remain in high state of efficiency, there must be adequate training of the workforce. Training is an important ingredient in any organization irrespective of size. When workers are regularly trained, it becomes easy for the organization to achieve its set goal. This paper examines human resource training as a way of improving workers performance in the civil service; a study of Isaac Jasper Boro College of Education Sagbama, Bayelsa State. Primary and secondary data were used to achieve the objective of the study. The survey research design method was used to obtain the primary data. That is, questionnaire was designed and administered to the target respondents. The simple random sampling technique was adopted to ensure that every member of the population is given equal chance to be included for the study. Data collected from the field was analyzed using arithmetic mean. The secondary sources of data include textbooks and journal articles. The result from the findings revealed that human resource training improves workers performance and productivity, prepare workers for higher responsibility, among others. The findings also revealed that staff training should be organized regularly and training should cut across all categories of staff in the organization. The paper therefore recommend that regular staff training programmes should be organized for workers and management should sponsored workers to attend conferences, workshops and seminars both within and outside Nigeria in order to improve their job performance.
\end{abstract}

Keywords: Human Resource, Training, Performance, Organization. 


\section{INTRODUCTION}

Human resource is the heart of every organization be it public or private. This is because every other resource such as money, material, machinery etc. depends on the human resource for the effective utilization and actualization of organizational goals. For the human resource to remain in high state of performance in order to achieve the goals of the organization, the workforce must be adequately equipped with the right skills and knowledge to carry out their duties. In other words, there must be some levels of training giving to the workers to help them meet the demands of their job and the organization in general.

The moment an organisation recruits' individuals it must integrate them into the organisation in order to achieve both individual and organisational goals. Such induction training is the employee first exposure to the organisation. Beyond induction training, there is need to continuously train and retrain workers for enhance job performance. This is because workers need to be abreast with technological and environmental changes in order to meet the demands of the dynamic situation under which the organisation function. As Cole (2002:14) rightly said "the training and development of employees is an issue that has to be faced by every organization. What Cole is saying in essence is that organization cannot do without the training of its workforce if it must achieve its corporate goals.

It is worthy to note that staff training activities are important for improving workers' performance both in public and private organizations. Drucker (1986) posited that a good organisational structure itself does not guarantee good performance, it is the human resource training and development that equip workers with the relevant professional skills that brings about efficient job performance. This position is supported by Pye (1988) cited by (Mukoro 2007) when she stated that "when steps are to be taken to improve the quality of employees and overall organisational performance, attention naturally turns to the process of training, education and development of employees. Even the architects of the 1988 Civil Service reforms could be said to have subscribed to Pye's submission as in relation to human resource training. For example, Section 4(1) of the reform state that for the purpose of improving economy and efficiency in the operation of a ministry and raising the standards of performance by employees of their official duties to the maximum possible level of proficiency, the minister shall establish, operate and maintain programmes or plans for training of employees in or under the ministry by and through government facilities including training institution (Mukoro, 2007).

No wonder Abubakar (1992) pointed out that human resource training is a sine qua non for the attainment of efficiency and effectiveness which are the two major goals/objectives of a good Civil Service.

\section{STATEMENT OF PROBLEM}

Organizations are established to achieve goals. These goals could be long or short term depending on the nature of the organization. In cause of achieving these goals most organizations come across a lot of problems. One of such problem is the issue workers performance. The problem of workers performance and productivity is a major challenge 
facing most organizations. This is because the performance/productivity of the workforce to a large extent determines how successful the organization will be. When workers are not given the right skill and knowledge, it becomes very difficult for them to performance their job effectively. The resultant effect of such poor performance is that it affects organizational productivity. The problem therefore is how to identify the conditions that requires that workers need training and also how workers can be effectively trained in order to enhance their performance.

\section{OBJECTIVE OF THE STUDY}

The broad objective of this paper is to examine staff training and its impact on workers performance. The specific objectives are to:

- Examine the impact of human resource training on workers performance.

- Identify conditions requiring staff training

- Proffer solutions and make recommendations on how best to train workers to achieve optimum output for the betterment of both the organization and the worker.

\section{RESEARCH QUESTIONS}

- Have you been sent for any staff training programme.

- What are the benefits of staff training?

- What measures should your management adopt to enhance workers performance.

\section{THEORETICAL FRAMEWORK}

Taylor introduced the scientific study of work method in order to improve workers' efficiency in the organisation. The concept of work efficiency was first put forward by Frederick Winslow Taylor in his 1911 publication, “the principles of scientific management'. Taylor pioneered a method now known as "time-and-motion" study, for determining the best way to reduce time and effort in order to improve work efficiency. This according Taylor can be achieved through systematic training and retraining of the workers. He insisted that it is the duty of management to give each workers the formal training and specific instructions on how to perform every piece of work with the standardized tools and materials (Wei and Taormina 2011, Sapru 2013). It is worthy to mention that workers performance is the driving force of every organization which can only be achieved through continuous training of the workforce.

The relevance of Taylor's theory to this paper is that it makes management know that staff training is the responsibility of the management and not the workers. This is because when workers are well trained it increases the productive capacity of the organization.

\section{REVIEW OF LITERATURE}

\section{MEANING OF TRAINING/HUMAN RESOURCE TRAINING}

Training has been defined in many different contexts depending on the stand point of the person defining it, thus bringing to conclusion that there is no universally accepted definition of training. 
Gupta (2006) defined training as the process of refining and increasing skills and abilities of individual towards best performance of a particular job in which training is imparted. Abiodun(1999) posited that training is "a systematic development of the knowledge, skills and attitudes required by employees to perform adequately on a given task or job". From the above definitions, training can be defined as the systematic impartation of knowledge, skill and attitude on an individual or group with a view to make them improve their performance. It should be noted that the essence of training any individual is to make him/her better in terms of performance compared to when he/she has not been trained. Therefore, every training programme should improve the individual in terms of knowledge, skill, attitude and even communication.

Human resource training therefore is the process by which an organisation ensure that it workforce is given the right skills, attitude to cope with the changes of time and technology. Human resources training in its myriad forms is provided to help employees learn job-related skills and obtain knowledge that will help them improve their job performance and further the organisation goals.

According to Nadler (1992), human resource training prepares employee so that he can move with the organisation as it develops and grows, resulting in new jobs for the employees at a higher level. What Nadler is saying is that the overall purpose of training an employee is to produce a viable and flexible workforce for the organisation as it moves towards the future.

The purposes of human resource training in a work situation are to develop the abilities of the individual and to satisfy the current and future needs of the organisation. Unlike education, which involves equipping employees to expand their capacity to learn and to perform in the future, human resource training according to Walker (1992) is specifically about providing a range of learning experience in a work experience. Critically speaking, employees' performance on the job in terms of efficiency is tied to the amount of training which the employee receives. Speaking on human resource training in the Civil Service, Mukoro (2007) posited that human resources training and development has never been given the needed priority in the Civil Service. It is therefore not out of place to conclude that the inefficiency in the public service is as a result of inadequate training and retraining of the workforce. To this end Ademolekun (1986) made a strong case for a "positive conception of the Civil Service" that would be able to carry out the contractual obligation between government and the governed whereby services would be seen to be provided efficiently and the system would run on smooth wheels. This position is reflected on the revised guidelines for training in the Federal Civil Service (1995), where it is unequivocally stated that "Government continues to accept the need and wisdom to use training as a vehicle for enhancing productivity and efficiency in the service (Mukoro, 2007).

A good reference point for human resources training and development in the Nigerian Civil Service is the Udoji Report of 1974. The position of this report was that "the new style, result-oriented public service envisaged could not come into being unless the training of all categories of Public Servant was stepped up" (Balogun and Oshionebo, 1985). 
It should be pointed out that the essence of human resources training is to improve efficiency in the work place and increase productivity. If human resource training is to improve performance and personnel efficiency, then training policies must be adequate to determine who should be trained in what, where, when and how. This is because the training could be a waste of time and resources if the area of emphasis in training is not properly isolated. Nothing can be more frustrating and demoralizing as teaching a person what he/she already knows. Concerted effort must be made to clearly identify areas of stress before embarking on any staff training programme.

\section{STAFF TRAINING METHOD}

Generally, staff training method in any organization falls into two broad categories: on-thejob training and off-the-job training. On-the-job training takes place concurrently with the job at the place of work. Off-the-job training on the other hand is organised away from the normal work situation, such as training institutions, centres, etc.

Several on-the-job training methods are used to help workers acquire the right skill, knowledge, and attitude necessary for a job. On-the-job trainings include the following:

- Induction: Also known as orientation is designed to help workers familiarized with the organization profile, background, structure, rules and regulations. Induction programmes provide new employees with some insight into the organization's practices and procedure, their duties and responsibilities towards the organization.

- Apprenticeship: This is training provided by working under an experienced worker or master in a craft. The apprentice works under a superior officer skilled in the craft and is taught by that superior person. After understanding the superior or master, the apprentice may take over his duties. According to Cupta (2006), apprenticeship training is compulsory in certain occupation. Some of the areas for apprenticeship training include:

- Building Construction

- Skill craft like those of Mechanics, electricians, welders etc.

- Professional lines like chartered accountants, lawyers, marketing, secretaries etc.

- Mentoring: Mentoring is a method of training where a superior person or someone who is more knowledgeable on the job, is assigned to a subordinate to guide and /or advise him or her in 'learning the ropes' of the organisation and the job. The employee is usually encouraged to seek necessary advice regarding the job and the organisation from his/her mentor from time to time.

- Staff Development Meetings: These are performance improvement oriented meeting aimed at exploring better ways of doing a job. Staff development meeting such as retreat could be organised away from normal work environment.

Off the job training takes several forms. The common ones include:

- Education by Correspondence: Employees are sometimes encouraged to undergo staff development oriented courses in reputable educational institution. This is to enable them acquire more knowledge about the job and broaden their experience. 
- Outside Work Situation Training: This entails an in house training away from the normal work situation. It is a kind of training conducted by educational institutions such as Lagos Business School, professional bodies like Nigerian Institute of Management and private consulting or training firms like Accenture. Outside work-situation training programme takes the form of workshop, seminars, and short time courses.

- Conferences and Workshop: This is another method of training employees. Learning experiences are gained from conferences and workshops organized by trade unions and professional bodies. Such conferences and workshops are designed to impart contemporary knowledge and ways of performing works on their members.

- Vestibule Training: Vestibule training is organised to give rapid training to employees who are about to be assigned to special machines and operations. The trainees would be taught the fundamentals of the job they were to perform. Vestibule training is given in a classroom simulating a real plant. Here, the trainee learns how to handle one phase of the trade. Cupta (2006) posit that vestibule literally implies the porch or entrance to the main building so that without passing through it, one's entry into the main building is not possible. The idea of vestibule training is that unless and until a person successfully undergoes the training, he/she is not allowed to be placed on the actual job.

\section{OBJECTIVE OF HUMAN RESOURCE TRAINING}

Every human resource training programme whether in the public or private sector is geared towards achieving a particular objective. Some of the objectives of human resource training identified by Nwachukwu (2007) include:

- Increased Productivity: Increase productivity is at the apex of all human resource training programme. A well trained employee is capable of producing more than an untrained employee of equal physical ability.

- Lower Turnover Rate: An employee who is incapable of producing is frustrated by failure and is more likely to abandon his/her work than those who are capable of producing. An untrained employee is like a dull school pupil, he hates school and likes to absent him/herself and he/she is likely to be school dropout unlike other pupils who enjoy school because they are doing very well. The same situation applies to an untrained and unproductive employee. They hate the job and abandon it at the slightest provocation from any source.

- High Morale: An employee who is trained has confidence in his ability to perform. $\mathrm{He} / \mathrm{she}$ believes that they have control of the work environment and is equipped to tolerate occasional disappointments, frustrations and inconveniences. He learns to rationalize and accept blame for his own failure instead of blaming the organization. A trained employee derives intrinsic satisfaction from work which promotes his morale.

- Improve Workers/Organizational Efficiency: Human resource training is aimed at improving organizational performance and efficiency. Organization needs to be efficient in order to compete and survive in the modern economic environment. Thus, organizational efficiency can be achieved through training and retraining of the workforce. 


\section{CONDITIONS REQUIRING STAFF TRAINING}

There are certain conditions that will serve as pointers for workers training. According to (Nwachukwu, 2007), these symptoms manifest themselves in a variety of ways. When an organisation starts experiencing or noticing these symptoms among the workers, it should consider training. Some of the most common symptoms are:

- Lack of Interest in the Job. Lack of interest in the job means when the worker no longer find pleasure in his/her work. The worker sees the work as a burden and a load. $\mathrm{He} / \mathrm{she}$ always find the work as irritating and if possible will avoid the job.

- Negative Attitude to Work: This is another symptom showing that a worker needs training. Negative attitude to work means when a worker does not take his/her work serious thereby displaying character and behaviour that affect the work and the organisation.

- Insubordination: This occurs when the worker no longer respect constituted authority in the organisation. The worker displays attitude of rudeness and sometimes refuses to accept responsibility and carry out instructions from his/her superior.

- Inefficiency: It means when input is more than outputs of the organisation. That is, low output in terms of productivity sales and services rendered which is tied to the workforce of the organisation. When organization starts experiencing such ugly situation, the solution is training and retraining of the workforce.

\section{NEGATIVE EFFECTS OF LACK OF TRAINING IN THE WORKPLACE}

There are several negative effects associated with lack of staff training in the workplace. Some of these negative effects include:

- Unhappy Employee and High Rate of Staff Turnover: Employees are interested in performing their jobs well in order to advance the organisation, feel a sense of pride for the job well done and advance to higher positions when they are happy. When there is no staff training, workers are unhappy which affects their morale and can result to high rate of employee turnover. The Hawthorne studies and many other researches on staff productivity discovered that employees who are satisfied with their job will have higher job performance, and thus supreme job retention than those who are not happy with their jobs (Landy, 1985).

- Low Rate of Production: The rate of production and performance is low when employees don't have good knowledge about their jobs. You cannot give what you don't have. Unskilled employees could spend considerable time seeking help to perform their job or they could perform task to their understanding which can be detrimental to the organization. This could lead to errors and work needing to be repeated or corrected. The result of all these is that it leads to low rate of production and performance.

- Unsafe Work Environment: Occupational Safety and Health Administrators states that untrained workers are more susceptible to injuries than trained workers. This occurs when workers lack the knowledge and skill required to use equipment and supplies safely. The problem could be fatal in work environments that contain heavy-duty machinery and hazardous materials. It is not enough to have established procedures and protocols for 
activities that involve potential safety risk. Workers must receive adequate training on the procedure and how and when to use them in order to avoid fatal accident.

\section{METHOD OF THE STUDY}

Survey design was employed in this study to elicit information from staff of Bayelsa State Polytechnic Aleibiri on staff trainings and workers performance. The primary source of data was collected through questionnaire while the secondary sources include textbooks and journal articles.

The population of the study is 520 staff of the College. The sample size of 270 was derived using Taro Yemen's formulae; they were randomly selected using simple random sampling technique.

The modified structured questionnaire of Likert scale format of strongly agreed (SA), agreed (A), disagreed (D), and strongly disagreed (SD) was used as instrument for data collection. A pilot study was carried out with 20 staff of the College to establish the reliability of the data collection instrument in order to ensure consistency of the instrument. 270 questionnaires were distributed out of which 180 were retrieved.

The arithmetic mean is used to analyze the data collected from the respondents. A criterion mean of 2.5 was used in taking decision.

Table 1 Sample size

\begin{tabular}{|l|l|l|l|}
\hline S/N & ACADEMIC/NON-ACADEMIC & POPULATTION & SAMPLE SIZE \\
\hline 1 & ACADEMIC & 180 & $180 / 520 \times 270=93$ \\
2. & NON-ACADEMIC & 340 & $340 / 520 \times 270=177$ \\
& TOTAL & $\mathbf{5 2 0}$ & $\mathbf{2 7 0}$
\end{tabular}

Source: Registry 2020, Isaac Jasper Boro College of Education, Sagbama. 


\section{ANALYSIS OF RESEARCH QUESTIONS}

Research question one (1): What are the benefits of staff training in your institution?

Table 2.1 Breakdown of response from Item 1 - 4

\begin{tabular}{|c|c|c|}
\hline S/N & ITEM STATEMENT & $\mathbf{S}$ \\
& & $(4$ \\
\hline
\end{tabular}

$\begin{array}{llllllll}1 & \text { Staff training improve workers } & 91 & 77 & 7 & 5 & 180\end{array}$

performance and productivity

\begin{tabular}{c|c|c|c|c|c|}
\hline SA & A & SD & D & TOTAL & XW \\
$(4)$ & $(3)$ & $(2)$ & $(1)$ & & \\
\hline
\end{tabular}

Weight of response

(364) (231)

(14) (5) 584

$\begin{array}{llllllll}2 & \text { Staff training increases organizational } & 83 & 84 & 5 & 8 & 180\end{array}$ productivity

Weight of response

$\begin{array}{lllllllll}3 & \text { Staff training leads to improve job } & 75 & 76 & 14 & 15 & 180\end{array}$ performance.

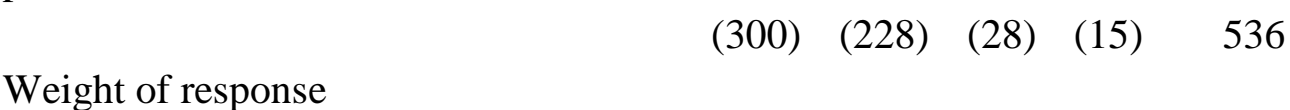

Weight of response

$\begin{array}{lllllllll}4 & \text { Staff training prepares } & \text { workers for } & 83 & 67 & 17 & 13 & 180\end{array}$ higher responsibility

Weight of response

Source: Field Survey 2020

$\mathrm{TW}=$ Total Weight

XW $=$ Mean of Weighted Scores .

Figures in Bracket ( ) are weighted scores

Criterion Mean $=\mathrm{SA}(4)+\mathrm{A}(3)+\mathrm{D}(2)+\mathrm{SD}(1)$

$=\frac{4+3+2+1}{4}=\frac{10}{4}=2.5$

Weighted Mean $=\frac{\sum \mathrm{xw}}{\mathrm{N}}$

$=\frac{3.3+3.7+3.1+3.3}{4}=\frac{13}{4}=3.2$ 


\section{DECISION RULE}

We accept if the mean of weighted mean is greater than $(>)$ criterion mean and reject if criterion mean is greater than $(>)$ mean of weighted means. Criterion mean $(x)=2.5$, Mean $(\mathrm{x})$ of weighted means $=3.2$.

The mean $(\mathrm{x})$ of the weighted mean 3.2 is greater than $(>)$ the criterion mean of 2.5 , the response is positive. It therefore means that the item statements above in table 2.1 are the benefits of staff training.

\section{Research question two (2): What measures should your management adopt to enhance workers performance?}

Table 2.2: Breakdown of response from Item 5-8

\begin{tabular}{|l|l|l|l|l|l|l|l|l|}
\hline S/N & ITEM STATEMENT & $\begin{array}{l}\text { SA } \\
\mathbf{( 4 )}\end{array}$ & $\begin{array}{l}\text { A } \\
\mathbf{( 3 )}\end{array}$ & $\begin{array}{l}\text { SD } \\
\mathbf{( 2 )}\end{array}$ & $\begin{array}{l}\mathbf{D} \\
\mathbf{( 1 )}\end{array}$ & TOTAL & XW \\
\hline 5 & $\begin{array}{l}\text { Regular staff training programmes } \\
\text { should be organized by the } \\
\text { management. }\end{array}$ & & & 87 & 11 & 180 & \\
& & $(348)$ & $(222)$ & $(16)$ & $(11)$ & 597 & 3.3
\end{tabular}

Weight of response

$\begin{array}{lllllll}6 & \text { Staff should be giving study leave with } & 95 & 69 & 9 & 7 & 180\end{array}$ full pay to upgrade themselves academically

$(380) \quad(207) \quad(18) \quad(7) \quad 612$

Weight of response

$7 \quad$ Management should sponsored staff to

$\begin{array}{lllll}87 & 75 & 8 & 10 & 180\end{array}$
attend conferences and workshops organized by professional bodies.

Weight of response

$\begin{array}{lllllllll}8 & \text { Staff training should cut across all } & 80 & 72 & 18 & 10 & 180\end{array}$ categories of staff.

$(320) \quad(216) \quad(36) \quad(10) \quad 582$

Weight of response

\section{Source: Field Survey 2020}

\section{DECISION RULE}

We accept if mean (x) of weighted mean is greater than $(>)$ criterion mean and reject if criterion mean is greater than $(>)$ mean of weighted mean. Criterion mean $(x)=2.5$, Mean $(x)$ of weighted means $=3.3$.

Since the mean $(x)$ of the weighted mean 3.3 is greater than $(>)$ the criterion mean of 2.5 , the response is positive. It therefore means that the item statements above in table 2.2 are measures management should adopt to enhance workers performance. 


\section{FINDINGS}

The findings from the study revealed a lot of benefits associated with human resource training in an organization. Among such benefits are improved workers performance/productivity, human resource training, prepare workers for higher responsibility and increases the overall productivity of the organization. The above findings is in tandem with Drucker (1986), when he stated that a good organizational structure itself does not guarantee good performance, it is the human resource training and development that equip workers with the relevant professional skills that bring about efficient job performance. The findings also revealed that regular staff training programmes should be organized by organizations, organizations should sponsor their workers to attend conferences and workshops, among others.

\section{CONCLUTION}

Staff training is an important tool for the actualization of organizational goals and to revamp the performance of all the personnel for organizational growth and success. It is beneficial to both the organization and the workers. An employee will become more efficient and productive if he/she is giving the right training. Organizations both public and private can enhance the quality of the current employees by providing comprehensive training and retraining programme.

Training is essential not only to increase productivity but also to motivate and inspire workers by letting them know how important their jobs are and giving them all the information they need to perform those job.

\section{RECOMMENDATIONS}

The following recommendations are made from the findings:

- Organizations should organize staff training regularly to help workers acquire the required skills and knowledge that will enhance their job performance.

- Organizations should make it as a matter of policy to sponsor workers to attend international and local conferences, workshops and seminars organized by reputable professional and non-professional bodies.

- Staff training should cut across every cadre or category of staff in the organization.

- Organizations should grant study leave with full pay to staff intending to forward their education to help them upgrade themselves academically. 


\section{REFERENCES}

Abiodun, E.J.A (1999). Human resources management: An overview. Lagos, Concept Publication.

Abubakar, H.I (1992). "The philosophy and rationale for the civil service reorganization Decree

No. 43 of 1988” in Yahaya, A.D and Akinyele C.I (eds) new trends in personnel management: A book of reading. Lagos, ASCON.

Ademolekun, L. (1986). "Issues in the management of public service” in Olowu D. and Oshionebo (ed) manpower utilization and development in Nigeria: A post Udoji evaluation. Lagos, ASCON.

Balogun, M.J and Oshionebo B.O (1985). "Personnel management in the public sector: A survey

of development, 1960 - 1980" in Ademolekun (ed) Nigerian public administration 1960 - 1980, perspective and prospects. Ibadan, Heinemann Publishers.

Cole, G.A (2002). Personnel and human resource management. London, T.J International.

Drucker, P.F. (1986). The practice of management. New York, Pan Books.

Gupta, R.N. (20006). Business organization and management. New-Delhi, Schany and Company

Ltd.

Landy, F.W (1985). The psychology of work behaviour ( $3^{\text {rd }}$ ed.). Homewood, IL, Dorsey Press.

Michelle S (2019)The Negative Effects of a Lack of Training in the Workplace. Retrieved from

https://smallbusiness.chron.com/negative-effects-lack-training-workplace-45171.html

Mukoro, A. (2007). Human resources training and development for the civil service in Nigeria: A Delta State perspective. Charlotte, NC USA, Cataway Publishing Company.

Nadler, L. (1992). Development of human resources. Houston Texas, Gulf Publishing. New Jersey, Chatham House Publishers Inc.

Nwachukwu C.C (2007). Management theory and practice. Onitsha, Africana First Publishers 
Limited.

Pye, A. (1988). "Management training: Acts of faith, scenes of competence”. Journal of General

Management 13 (4) Summer.

Sapru R.K (2013). Administrative theories and management thought. Delhi, PHI Learning Private Limited.

Taormina, R.J and Wei, W (2011). Factors influencing work efficiency in China. Scientific Research, 1 (1) pp $56-63$.

Walker, W.J (1992). Human resources strategy. Singapore, Mc Graw-Hill. 